\title{
Science Learning Achievement; Three Dimension-Media Innovation in Contextual Learning Approach
}

\author{
I Wayan Widiana ${ }^{1 *}$, Nyoman Kusmariatni², Dewa Nyoman Sedana ${ }^{3}$, Putu Nanci Riastini ${ }^{4}$
}

1,2,3,4 Jurusan Pendidikan Guru Sekolah Dasar, Fakultas Ilmu Pendidikan, Universitas Pendidikan Ganesha, Singaraja

A R T I C L E I N F O

Article history:

Received 15 August

2019

Received in revised

Form 29 September

2019

Accepted 18 October

2019

Available online 29

November 2019

Keywords:

contextual learning

approach, three

dimension media,

learning achievement

\section{A B S T R A C T}

Science learning achievement is low in some elementry schools in Bali and it is suspected that learning process is one of the factors that has caused this. Hence, there is a need for innovations in learning to improve learning process which has so far taken place (conventional). This study wasa aimed at finnding out the difference in science learning achievement between students who are taught through contextual learning which uses three dimension media and those who are taught through conventional learning..this is a quasi-experimental research with non equivalent post-test only control group design. The population used in this study was the fourth grade students af elementary schools in Gugus 1 Singaraja with the total number of eight schools. The sample in this study was selected using random sampling. Out of the eight schools in Gugus 1 Singaraja, two schools wereselected, namely SD No. 5 Banyuning as experiment group and SD No.6 Banyuning as conrol group.. the data gathered inthis study was in the form of science learning achievement. The instrument used to collect the data was an objective test or multiple choice. The data were analyzed using inferential statistics or t-test. The result showed that science learning achievement in the group where three dimension media were used had the mean score of 20.75 , which is higher than the group where conventional learning was used, whose mean score was 17 . 08. This result was confirmed by hypothesis testing in which it was obtained that tobs. > tc.v.. This means that the implementation of contextual learning approach which was aided with three dimenisionmedia had a positive effect on science learning achivement.. 


\section{Introduction}

Naturally, science is a knowledge about natural phenomena which are stated as facts, concepts, principles, and laws the truth of which is verified through a series of activities using the scientific method. And science alo gives insights to us on how we can live by adaptation to those facts.. The nature of science as product and process cannot be differentiated or separated, since the product and process have related relations with each other in doing a scientific observation (Bundu, 2006; Trianto, 2010). According to Djojosoediro (2010) in terms of its characteristics, science is related to the way to find out about nature systematically, so that science is not only the acquisiton of a group of knowledges in the form of facts,concepts, or principles only, but it also constitutes a process of invention..

The objectives of science at elementary school according to the Regulation of the Minister of the National Education No. 22 of 2006 are for the students to have the following abilities: 1) to obtain belief in the greatness of God, the Almighty based on the existence, beauty and regularity of the nature created by Him, 2) to develop knowledge and understanding of science concepts which are useful and can be implemented in daily life, 3) to develop curiosity, positive attitude and relationships which influence each other among science, environment, technology and society. 4) to develop process skill to investigate the surrounding nature, to spolve problems and to make decisions, 5) to improve the awareness to participate in taking care of, keeping and preserve the natural enviroment, 6) to increase the awareness to appreciate the nature and all of its regularities as one of the creations of God, and 7) to acquire knowledge, concepts, skills in science as the foundation to continue to SMP/MTs.

Basad on the objectives above Science for Elementary School is expected to be used as a means for the students to learn about themselves and the natural environment, and further prospect in daily life (Djojosoediro, 2010). But Science learning achievement in some elementary schools in Gugus 1 Singaraja Buleleng Bali is diferent from the expectation. The reality shows that in Semester 129 out of 48 students (60.42\%) did not meet the minimum mastery requirement (65) in Science.The record shows that the students had not been able to perform abstract thinking They had difficulties in understanding lessons, especially abstract concepts. This becomes the main problem that needs to be solved at elemetary schools in Bali so that the students understand and master Science that they learn..

The results of observation and further interview with the students and the teachers show that in general there are some things which cause the low learning achievement in Science which include insufficient infrastructure and facilities, teaching and learning process, and assessment used. Especially in the teaching and learning process it was found that 1) insufficient attention of the teachers to the importance of contextual learning approach in increasing the students'learning motivation and the students' learning achievement; 2) the still frequent use by the teachers of lecture method in the implementatin of teaching and learning activities, the not yet common use of media at school, in the sense that not all Science teachers use media in teaching. This is caused by the fact that awareness has not yeat developed among the teachers about the importance of media and their effect on the teaching and learning activities, especially in Science teaching and learing activities ; 3 ) insufficient attention of the teachers to the students during the teaching and learning activities so that the students' attention was low and they were less enthusiastic in learning; 4) in teaching the teachers only have the students learn something in rote and there is an impression that they teachers do most of the activities and the students are less active. The less active students in learning can cause them to become lazy, bored, and not willing to pay good attention so that the situation in the classroom become noisy and the implementation of the teaching less condusive. Thus, Science teaching and learning process at elementary schools now are still oriented toward activities that are dominated by the teachers. The students' participation in learning is still limited to the reception of materials that the teacher teach through a lecture. In learning the students are still pasive an wait for information, notes or questions from the teacher. This has an impact on the students' understanding of concepts.

Looking at the casues of the problem, one of the efforts to increase the students' learning achievement at school is made through improving the teching and learning proces. This is supported by Handayani (2009) who states that teaching is a way on the part of the teachers who in doing their function are instruments to achieve the learning objectives. Teaching method is more procedural and contains certain steps. Learning objectives are the realization of efficiency and effectiveness in learning activities which are done by the students. Joyce \& Weil (1980) define teaching model as a conceptual framework used as the guideline in implementing the teaching. Thus, teaching model is a conceptual framework that describes systematic procedures in organizing learning experiences to reach learning objectives.

Improvement in Science teaching process has to emphasize the giving of direct experiences to develop competences in order the students understand natural environement scientifically. Teaching has 
to be based on constructivist paradigm. An innovative teaching which is based on constructivist paradigm helps the students to internalize, reconstruct, or transform new information. Transformation occurs through the creation of a new understanding (Gardner, 1991) which is the result of the emergence of a new cognitive structure. In the constructivist class setting, the students are responsible for their learning, become autonomous thinkers, develop integrated concepts, develop quesions that are challenging and find answers independently (Brook \& Brook, 1993; Duit, 1996; Savery \& Duffy, 1996). Previous studies have revealed that an innovative teaching can improve the students' learnng process and learning achievement (Ardhana et al., 2003; Sadia et al., 2004; Santyasa et al., 2007).

Bruner (in Sukayati, 2003) states that students in learning Science concepts go through three stages, namely eamctove. Iconic and symbolic stages. Enactive stage is the learng stage with concrete objects manipulation, Iconic stage is the stage of learning with pictures, and symbolic stage is the stage of learning mathematics through symbols manipulation. On the other hand, Piaget states elementary school children are still in concrete operational stage. It means that to understand a concept the students have to be given activities that are related to real objects or real events which can be received by their mind.

Based on the above theory, one of the steps in the innovative teaching offered to the teachers is the use of three dimensions media in contectual teaching and learning (CTL) approach, whose implication is that the students have a strong interest in the concepts taught by the teacher. Wht is meant by three dimensions media is a group of media without projection whose presentation is visually and in three dimensions. It means that the media is real and can take the form of artificial objects. This media is very suitable with the charcteritics of contextual approach. Handayani (2009) points outt that one of the efforts to enhance the quality of educaion is made through the use of active learning, that is by using CTL. Adhi (1996) points out that contectual teaching and learning which is used appropriately will always encourage the students to relate what they learn to their previous experiences and to related what they learning to daily life events.

In CTL there is the possibility for five important forms of learning to occur, namely, (1) relating, which is the most effective strategy and is the core of constructivism. The teacher is using this $\mathrm{s}$ trategy when he or she is relating a new concept to the concept already known by the students. Thus, relating what has been known by the students to new information. (2) experiencing is the core of contextual teaching and learning in which the teacher is relating new information to the old experiences and knowledge. Learning can occur more quickly when the students can manipulate tools and materials and conduct active forms of research. (3) applying, namely applying a concept when the students are soving problems. The teacher can motivate the students by giving practices which are realistic and relevant (4) Cooperating, that is the students who are working individually often do not contribute to a significant progress. On the contrary, the students who work in groups can often solve complex problem with a little help. Experiences in cooperating with others do not only halp the students to learn the learning materials, bu are consistent with the real world. The last form of learning is (5) transferring, which means the teacher has the role to develop a varieity of learning experiences. With the focus on understanding rather not rote learning (Yasa, 2010).

A study on Contextual Teaching and Learning has been conducted to find out its effectiveness in improving the students' learfning achievement. Suantini, Jampel, \& Widiana (2013) and Puspaniati, Ketut Suarni, \& Widiana (2014) in their studies found that CLT had positve a effect on the studeants' learning achievement.at elementary school.. Suantini, et al (2013) in their study integrated CLT and Balinese local content to facilitate the students' learning. While Puspaniati, et al. (2014) state that by adding KIT media students can understand science concepts more easily. One needs to be aware that conterxtual approach puts very much emphasis on the students' learning activity in constructing their onwn understanding. In this construction process there will be many problems faced if the media used are only real media. The problems occur since there are topics which cannot be taaught through real media. For example, in introducing human body organs in Science, in introducing past cultures in Social Sciences, etc. these problems can only be solved by using media which resemble the real objects.

According to Daryanto (2012) three dimension media are a group of media without projection and their presentation are done visually with three dimensions. Aor visual aids with length, width and height so that they can have a volume (or content). The three dimension media in this study are media which are made for instruction based on the development of teaching materials for the sixth grade students of elementary school. The objective of making this group of media is in order the media resembel real objects, living or dead objects and imitation and representation of the real objects. The real objects when used as teaching media can be brought directly into the classroom, or the students in the class are taken directly to to the real worldl in which the object is found. If it is difficult to bring the real object into the classroom, or when the students cannot directly face the place where the oubject exists, then the imitated objects can also function as an effective teaching media.. Three dimension media produced belong to 
simple media since in the proces of making of the media the maker does not a special skill. They can be made by the teachers themselves, and the materials can be easily foudn from the surrounding.

In relation to the effectiveness in using the media in teaching, Brown (1973) states that the teaching media used in teaching can influence the teaching effectivnees.On the other hand, according to Briggs (1977) teaching media is a physical facility to communicate the content of the teaching materials such as : books, film, video, etc. Then, according to National Education Associaton (1969) teaching media is the means of communication in the form of print, audio-visual, including technological hard ware. Suryosubrata (1996) states that various concepts and new insights about teaching at school have appeared and developed simultaneously with the rapid development in knowledge and technology. Adhi (1996) states that: "instructinal technology is an attempt that can be made to improve the quality of teaching. The concept of instructional technology is a system of educational technology which provides an alternative to the instructional program design. The use of teaching media can improve the effectiveness and efficiency of teaching process."

This is also supported by the result of the work by Septian \& Tampubolon (2015) which shows that the students who were taught by three dimesion media (3D) obtained a high learning achievement score than that of those who were taught by conventional media. Hence, it can be concluded that the use of three dimension media (3D) has a significantly different effect on the drawing learning achievement with a software at SMKI Negeri 2 Meolaboh in the academic year 2014/2015. Furthermore, Risnawati (2013) found that the use of three dimension media could improve teacher activity, student activity and student learning achievement among the students of Grade IIIC at SDN Manukan Kulon Tandes Surabaya. The result shows that the percentage of teacher activity underwent a $13.5 \%$ increase from $74 \%$ in cycle I to $87.5 \%$ in cycle II. Student activity increased by $20 \%$ from $74 \%$ in cycle 1 to $94 \%$ in cycle II. The students' learning achievement also underwent an increase from $1.63 \%$ in cycle 1 to $89 \%$ in cycle II.

This study has evaluated the result of a three dimension media development in contextual teaching and learning at elementary school in improving Science learning achievment of the sixth grade students. The evaluation was done by looking at the effect of three dimension media in contexctual teaching and learning at the elementary school on Science learning achievmenet of the sixth grade students.

\section{Methods}

According to research classification by Tjokonegoro (1999) this study is an experimental research. This study was conducted at elemetary schools of Gugus I Singraja from September to October 2016. The population was the sixth grade students in Gugus 1 Singaraja with the total number of 8 schools. The sample selected in this study was random sampling. Out of the eight schools in Gugus I Singaraja, two schoos were selected, they were SD No. 5 Banyuning as experiment group and SD Nol 6 Banyuning as control group. The sample consisted of 48 students comprising 20 males and 28 females.

To obtain data about Science learning achievement an achievement test instrument was used consisting of items which were based on the items in the topics of the lessons that had been taught. The test used to collect data about Science learning achievement was a multiple choice objective test with one correct answer. There were 25 test items, in which each item was assigned 1 if a student answered it correctly (according to the answer key) and 0 if the student answered it wrongly. To analyze the data the t-test of quantitative data analysis method was used. After a hypothesis testing was done, the prerequisite test was conducted, in which normality test was done to test the normality and homogeneity test to test at the homogeneity of the data. To give a picture about the study data description evaluation scale table is given in Table 1.

Table 1. Evaluation Scale Criteria

\begin{tabular}{lll}
\hline Score Range & Real Score Range & Category \\
\hline $\mathrm{Mi}+1.5 \mathrm{SDi} \leq \mathrm{X} \leq \mathrm{Mi}+3.0 \mathrm{SDi}$ & $18.76 \leq \mathrm{X} \leq 25.01$ & Very High \\
$\mathrm{Mi}+0.5 \mathrm{SDi} \leq \mathrm{X}<\mathrm{Mi}+1.5 \mathrm{SDi}$ & $14.59 \leq \mathrm{X}<18.76$ & High \\
$\mathrm{Mi}-0.5 \mathrm{SDi} \leq \mathrm{X}<\mathrm{Mi}+0.5 \mathrm{SDi}$ & $10.42 \leq \mathrm{X}<14.59$ & Medium \\
$\mathrm{Mi}-1.5 \mathrm{SDi} \leq \mathrm{X}<\mathrm{Mi}-0.5 \mathrm{SDi}$ & $6.25 \leq \mathrm{X}<10.42$ & Low \\
$\mathrm{Mi}-3.0 \mathrm{SDi} \leq \mathrm{X}<\mathrm{Mi}-1.5 \mathrm{SDi}$ & $0.01 \leq \mathrm{X}<6.25$ & Very Low \\
\hline
\end{tabular}




\section{Result And Discussion}

\section{Distribution of Data of the Experiment Group}

The result of posttest of the 24 students of the experiment group shows that the highest score was 24 and the lowest was 16. The distribution of the data analysis of Science learning achievement 1 of the experiment group is presented in Table $2 .$.

Table 2. Frequency Distribution of Science Learning Achievement of the Student of the Experiment Group

\begin{tabular}{llllr}
\hline Interval & $\begin{array}{l}\text { Class lower Limit } \\
\text { bawah kelas }\end{array}$ & $\begin{array}{l}\text { Middle Score } \\
(\mathrm{X})\end{array}$ & $\begin{array}{l}\text { Absolute } \\
\text { Frekuensi }\end{array}$ & $\begin{array}{r}\text { FrequencyRelative } \\
\text { Frequency Relatif }\end{array}$ \\
\hline $14-15$ & 13.5 & 14.5 & 1 & \\
$16-17$ & 15.5 & 16.5 & 2 & \\
$18-19$ & 17.5 & 18.5 & 3 & \\
$20-21$ & 19.5 & 20.5 & 8 & \\
$22-23$ & 21.5 & 22.5 & 7 & \\
$24-25$ & 23.5 & 24.5 & 3 & \\
\hline & Total & & 24 & \\
\hline
\end{tabular}

Based on the data anaysis, it is known that the mean score for Science learning achievement of the students of the experiment group after the implementation of Contextual Teaching and Learning approach aided with three dimension media was 20.75. When this score is converted into the critrion referenced evaluation with a five scale, it falls into very high category.

\section{Distribution of data for Control Group}

The result of posttest for the 24 students of the control gorup shows that the highest score is 23 and the lowest is 12 . The distribution of the data about the Science learning achievement of the students of the conrol group is presented in Table 3 .

Table 3. Frequency Distribution of Science Learning Achievment in the Students iin the Control Group

\begin{tabular}{lllll}
\hline Interval & Class lower Limit & Middle Score $(\mathrm{X})$ & $\begin{array}{l}\text { Absolute Frequency Frekuensi } \\
\text { Absolut (f0) }\end{array}$ & $\begin{array}{l}\text { Relative } \\
\text { Frequency }\end{array}$ \\
\hline $12-13$ & 11.5 & 12.5 & 2 & \\
$14-15$ & 13.5 & 14.5 & 3 & \\
$16-17$ & 15.5 & 16.5 & 9 & \\
$18-19$ & 17.5 & 18.5 & 7 & \\
$20-21$ & 19.5 & 20.5 & 2 & \\
$22-23$ & 21.5 & 22.5 & 1 & \\
\hline & & 24 & \\
\hline
\end{tabular}

Based on the data anaysis, it is known that the mean score for Science learning achievement of the students of the control group after the implementation of conventional teaching model was 17.08. When this score is converted into the critrion referenced evaluation with a five scale, it falls into high category.

\section{Result of Hypotthesis Testing}

Then before the hypothesis testing was done, some prerequisite tests had to be done, namely normality test and homogeneity test.. Based on the data analysis done, it was found that the $\chi^{2}$ value for the experiment group was 6.70 and the $\chi^{2}$ value for the control group was was 1.59 , both are smaller ( 7.815) than the critical value at the $5 \%$ level of significance. This means that the distribution of th data of the result of the study in the experiement group and the control group had normal distributions. On the other hand, the homogeneity testing done to the variances of the inter-group pair of the experiment and the control groups yielded $F_{\text {obs. }}=1.707$ smaller than Fc.v. at the 5\% level of significance was 2.040. This means that the variance of the data of the results of the study is homogeneous. 
After meeting the data anaysis prerequisites, the testing was continued with the testing of the study hypothesis. The hypothesis testing wass conducted by using independent t-test sample (uncorrelated) by using pooled variance formula. The criterion for computation is $\mathrm{H}_{0}$ is rejected if $t_{\mathrm{obs}}$. $>$ $t_{\text {tc.v.l }}$ and $H_{0}$ is accepted if $t_{\text {obs. }}<t_{\text {c.v. }}$. The recapitulation of the hypothesis testing is shown in table 4 .

Table 4. Recapitualition of the Result of Hypothesis Testing

\begin{tabular}{lcclccc}
\hline $\begin{array}{l}\text { Group } \\
\text { Data about Learning }(\mathrm{s} 2) \\
\text { Achievement }\end{array}$ & $\mathrm{n}$ & $\begin{array}{l}\mathrm{dF} \\
(\mathrm{n} 1+\mathrm{n} 2-2)\end{array}$ & Tobs. & Tc.v. & Conclusion \\
\hline Experiment Group & 7.99 & 24 & & & & Tobs. $>$ t c.v. \\
Control Group & 13.64 & 24 & & 3.87 & 1.697 & Hojected \\
\hline
\end{tabular}

Based on the result of the t-test computation result, it was obtained that $t_{\text {obs }}$ was 0.949 . On the while, , $t_{\text {c.v. }}$ wt df. $=46$ and at the $5 \%$ level of significance is 1.669 . this means that $t$ obs. is greater than $t_{\text {c.v. }}\left(t_{\text {obs. }}>t_{\text {c.v. }}\right)$ thus, $\mathrm{HO}$ is rejected and $\mathrm{H} 1$ is accepted. Hence, it can be interpreeted that there is a significant difference in Science learning achievement between the group of students who learned through Contextual Teaching and Learning approach aided with three dimension media and the group of students who learned through conventional teaching model. If we see from the mean scores of the two groups we see that Science learning achievement of the experiment group is 20.75 and that of the control group is 17. 08. This means that Science learning achievement of the students taught by Contextual Teaching and Learning approach aided with three dimension media is better than that of those taught by conventional learning.

\section{Discussion}

The discussion of the results of study and the testing of hypothesis about Science learning achievement, especially in reproduction of living creatures, environment and plants, Contextual Teaching and Learning model aided with three dimension media had a different effect on Science learning achievement which was applied to the experiment group compared to conventional teaching model which was applied to control group. This can be seen from the results of analyses of the ability to solve Science problemsm in this case, descriptive analysis and inferential analysis ( $t$-test).

Descriptively, the ability to solve Science learning achievement of the students of the experiment group was higher than that of the control group. This conclusion was based on the mean scores of Science learning achievement and the slope of the polygon curve. The mean score of Science learning achievement of the group of students in the experiment group was 20.75 , falling into very high category, while that of the control group was 17.08, falling into high category.If the abilities of the students of the experiment group are drawn in a polygon graph, it will be seen that the curve of the data distribution will slant negatively which means that most of the Science scores of the students tend to be high. In the control group, if the abilities of the students of the control group are drawn in a polygon graph, it will be seen that the cure of the data distribution will slant positively which means that most of the Science score of the students tend to be low.

Based on the inferential analysis using the t-test which is shown in Table 10 it is known that $t_{\text {obs. }}$ $=3.87$ and $t_{\text {c.v. }}(\mathrm{df}=46$ at the $5 \%$ level of significance $)=1.697$. The result of the computation shows that $t_{\text {obs. }}$ is greater than $t_{\text {c.v. }}\left(t_{\text {obs. }}>t_{\text {c.v. }}\right)$ so that the result of this study is significant. This means that there is a significant difference in Science learning achievement between the group of students who learned through Contextual Teaching and Learning aided with three dimension media and those who learned through conventional teaching model. The significant difference shows that the implementation of Contextual Teaching and Learning approach aided by three dimension media has the effect of the abilityh to solve Science prolems. This supports the finding of Nyoman Setiawan (2012), which states that there is a significant difference in Science learning achievement between the group of students who learned through Contextual Teaching and Learaning model and those who learned through conventional teaching model..

The strengths of the effect of the Contextual Teaching and Learning approach aided with three dimension media on Science learning achievement and Conventional Teaching model can be seen from the descriptive analysis which shows that that the Science learning achievement of the experiment group 
is better than that of the control group. Hence, it can be concluded that the teaching and learning process which uses Contextual Teaching and Learning approach aided with three dimension media had a positive effect on Science learning achievement of the sixth grade students of SD Negeri in Gugus 1 Singaraja. This also supports the result of Widiana (2014) which shows that there is a significant difference in Science learning achievement between the students who learned through Contextual Teaching and Learning and that of those who learned through conventional teaching model. This can be seen from the mean score of the experiment group which was higher than that of the control group (the mean score of the experiment group $=10,50>$ that of the control group $=8.81$ ) and the testing of the hypothesis usng t-test which showed that $t_{\text {obs. }}$ was greater than $t_{c v}$. $\left(t_{o b s .}=3.027>t\right.$ tabel $\left.=2.000\right)$.

The results that show that Contextual Teaching and Learning model aided with three dimension media have a positive effect on Science learning achievement with the tendency that most scores of the students are high is caused by some factors. The first factor is that in the teaching and learning process, the students are involved activiely in the group. The interaction which occurs om tje group brings with it a nurturing effect in the form of llinguistic aspect. This linguistic aspect will help the students in investigate problems. The improvement in the students' linguistic aspect could be seen from the students' ability in defining the problems The students could corectly write the planning of how to solve problems which were started with the making of problem solving plan which consisted of thee components, namely Given, Asked, Answered. Different from the situation before the implementation of Contextual Teaching and Learning aided with three dimension media, the students were confused especailly in formulating Given, and Answered since they did not know what were ment

The second factor is that in teaching the students, the teachers positioned themselves as mediators and facilitators at the time when the focus of teaching and learning activity was presented by using three dimension media. The students were directed to determine their learning activities according to the problems given so that the students were active in constructing their own knowledge. This conforms to Elliot's view (in Abimanyu, 2008) that teaching will be more meaningful and permanent if the students are given the opportunity to actively build their knowledge by themselves ".

In addition to the factors above, there are other factors which are related to the use of three dimension media. First, the students feel that they are motivated to practice to improve their mastery of concepts. This has a similar effect to the use of problem solving strategy in Science which makes the teaching more meaningful to the students. This occurs since in the teaching process, the materials are related to the students' daily real life. Secondly, the students' learning activities will increase. This is seen from the intensity of the students' questions which they ask to the students. Similarly, the discussion in the small group is more conducive. This is also indicated by the fact that the teachers become less dominant. The students can solve the problems in Science more independently compared to the time before the implementation of the three dimension media. This is in line with Sudarsana's finding (2010) that the decrease in the teacher's dominance and the increase in the students' activity in the teaching process show that the implementation of Contextual Teaching and Learning aided with three dimension media is successful in imrpoving the students' Science learning achievement.

\section{Conclussion}

Based on the results of this study and the discussion above, it can be concluded that there was a significant differene in Science learning achievement between the group of students who learned through Contextual Teaching and Learning approach aided with three dimension media and those who learned through conventional teaching model among the sixth grade students of elemetary students in Gugus 1 Singarfaja. ( $\mathrm{t}$ obs. = 3. $87>$ tc.v. = 1.697). The mean score in Science learning achieveme3nt of the group of the students who learned through Conextual Teaching and Learning approach aided with three dimension media $=20.75>$ the mean score of those who learned through conventional teaching $=$ 17.08. The significant difference shows that the implementation of Contextual Teaching and Learning approach aided with three dimension media had a significant effect on Science learning achievement compared to the implementation of conventional teaching model.

Based on the result of this study it is suggested that the teachers in elementary schools in Gugus I should use Contextual Teaching and Learning approach aided with three dimension media to make the teaching and learning process more effective and to improve the students' learning achievement. 2) It is also suggestedd to the teachers that in the teaching and learning process they should implement an innovative teaching model which is supported by a relevant study technique to improve the students' learning achievement. 3) Finally, for other researchers who are interested in conducting a sudy it is suggested that those who do a further study on the use of Contextual Teaching and Learning approach aided with three dimension media in Science or other subject areas to consider the constraints faced such 
as the difficulty in implementing a teaching and learning method to achieve a good learnng achievement, thus in a further research the constraints can be used as the considerations for the improvement of a research that will be done later.

\section{Reference}

Abimanyu, Soli, dkk. 2008. Strategi Pembelajaran. Ditjen Dikti Depdiknas. Jakarta.

Adhi. Made Kertha. 1996. Strategi Belajar Mengajar. Tabanan: Institut Keguruan dan Ilmu Pendidikan Saraswati.

Briggs, J.L. 1997. Instruction Design; Principle and Aplication. New York: Educational Technology Publication Inc.

Brooks, J.G. \& Brooks, M.G. 1993. In Search of Understanding: The Case for Constructivist Classroom. Alexandria, VA: Assocation for Supervision and Curriculum Development.

Brown, Douglas H. 1973. Principles of Language Teaching and Learning. New Jersey: Prentice-Hall

Bundu, Patta. 2006. Penilaian Keterampilan Proses dan Sikap Ilmiah dalam Pembelajaran Sains di SD. Jakarta: Depdiknas.

Daryanto, 2012. Media Pembelajaran,Bandung:Sarana Tutorial Nurani Sejahtera,2012,hlmn.29

Djojosoediro, Wasih. (2010). Pengembangan dan Pembelajaran IPA SD. Bandung:Refika Aditama.

Duit. et. al. 1989. Teacher Use of Analogies in Their Regular Teaching Routines. Reasearch In Sciene Education. 19. 291-299.

Gardner, 1991. Fisiologi Tanaman Budidaya. UI Press: Jakarta

Handayani. 2009. Pendekatan Pembelajaran Kontekstua Sebagai Upaya Meningkatkan Kemampuan Menulis Deskripsi pada Siswa Kelas X SMA Negeri 2 Demak Tahun Ajaran 2008/2009. Surakarta: Fakultas Keguruan dan Ilmu Pendidikan Universitas Muhammadiyah.

Joyce, Bruce and Weil, Marsha. 1980. Models of Teaching (Second Edition). Englewood Cliffs, New Jersey: Prentice-Hall, Inc.

Nyoman Setiawan . 2012. Pengembangan Model Asesmen Autentik Pembelajaran IPA Kontekstual Terintegrasi Dengan Model Pengajaran Berpikir Tingkat Tinggi Sebagai Upaya Meningkatkan Kompetensi Siswa SMP. Jurnal Pendidikan Indonesia. Vol. 1, No. 1, April 2012. http://ejournal.undiksha.ac.id/index.php/IPI/article/view/4482/3455.

Puspaniati, N. K., Ni, P., Suarni, K., Widiana, I. W., Pd, S., Pd, M., Bk, J. (2014). Pengaruh Model Contextual Teaching and Learning Berbantuan Media Kit IPA Terhadap Hasil Belajar IPA Pada Siswa Kelas IV SD Sidetapa, (1).

Risnawati, Lina. 2012. "Pengaruh Latar Belakang Pendidikan dan Perhatian Orang Tua Terhadap Prestasi Belajar Siswa Kelas V SD Cakraningratan No.32 Tahun Ajaran 2011/2012". Skripsi. Surkarta: UMS.

Sadia, I Wayan. 2008. Model Pembelajaran Yang Efektif Untuk Meningkatkan Keterampilan Berpikir Kritis Jurnal Pendidikan dan Pengajaran UNDIKSHA, No. 2 TH. XXXXI April 2008

Santyasa, I W. Model-Model Pembelajaaran Inovatif. Makalah Disajikan dalam pelatihan tentang Penelitian Tindakan Kelas bagi Guru-Guru SMP dan SMA di Nusa Penida ,tanggal 29 Juni s.d 1 Juli 2007

Savery, J.R., \& Duffy, T.M. (1995). Problem-based learning: An instructional model and its constructivist framework. In B. Wilson (Ed.), Constructivist learning environments: Case studies in instructional design (pp. 135-148). Englewood Cliffs, NJ: Educational Technology Publications. 
Septian, A., \& Tampubolon, J. (2015). Pengaruh Pembelajaran Menggunakan Media Tiga Dimensi (3d) Terhadap Hasil Belajar Menggambar Dengan Perangkat Lunak Kelas Xi Program Keahlian Teknik Gambar Bangunan Smk Negeri 2 Meulaboh, 1, 70-78.

Suantini, Yuni., Jampel, \& Widiana. 2013. Pengaruh Model Pembelajaran Kooperatif Tipe Circ Terhadap Pemahaman Konsep IPA Siswa Kelas IV Di Gugus II Kecamatan Gerokgak. Singaraja: Mimbar PGSD Undiksha.

Sukayanti. 2003. Pecahan. Yogyakarta: Departemen Pendidikan Nasional Dirjen Pendidikan Dsar dan Menengah. Pusat Pengembangan Penataran Guru (PPG) Matematika.

Suryasubrata, Soemadi. 1996. Psikologi Pendidikan. Bandung: Angkasa.

Tjokronegoro, A. 1999. Metodologi Penelitian Bidang Kedokteran. FKUI Jakarta

Trianto. 2010. Mendesain Model Pembelajaran Inovatif-Progresif. Jakarta: Kencana

Widiana. (2014). Pengaruh Model Contextu’al Teaching And Learning Berbantuan Media Kitipa Terhadap Hasil Belajar Ipa Pada Siswa Kelas IV Sd Sidetapa . Jurnal Mimbar PGSD Universitas Pendidikan Ganesha Jurusan PGSD (Vol: 2 No: 1 Tahun 2014) . http://ejournal.undiksha.ac.id/index.php/JJPGSD/article/viewFile/2228/1928 